\section{Substrate Drench Applications of Flurprimidol and Paclobutrazol Influence Growth of Swamp Sunflower}

\author{
Kaitlin Barrios ${ }^{1}$ and John M. Ruter ${ }^{1}$
}

ADDITIONAL INDEX WORDS. Asteraceae, chlorophyll meter, flower diameter, growth index, Helianthus simulans, plant growth regulator, plant height, SPAD

SuMmaRY. Swamp sunflower (Helianthus simulans) is an underused perennial plant native to the southeastern United States that produces an abundance of golden yellow inflorescences in the fall. It is a vigorous grower and tolerates a wide variety of soil conditions, growing in wetland and nonwetland habitats. Swamp sunflower warrants wider use in perennial beds and landscapes, and research on production practices to make plants more suitable for shipping could promote its production. This study evaluated the effects of plant growth regulators (PGRs) on the growth and floral attributes of the swamp sunflower. Treatments were applied to rooted cuttings in 1-gal pots as a substrate drench of $1,2,4$, or $6 \mathrm{mg} /$ pot paclobutrazol; $0.5,1,2$, or $4 \mathrm{mg} /$ pot flurprimidol; or water (control)/pot for Expt. 1. A second experiment (Expt. 2) applied 4, 6, or $8 \mathrm{mg} /$ pot paclobutrazol; 2, 4, or $6 \mathrm{mg} /$ pot flurprimidol; or water (control)/pot. Six weeks after treatment (WAT) for Expt. 1, paclobutrazol applied at 4 and $6 \mathrm{mg} /$ pot and flurprimidol at 2 and $4 \mathrm{mg} / \mathrm{pot}$ resulted in smaller plants (as reflected by growth index) by $29 \%, 34 \%, 22 \%$, and $48 \%$, respectively, compared with the control. Furthermore, at the termination (6 WAT) of Expt. 1, the highest rate of flurprimidol produced the smallest plants, with the exception of the highest rate of paclobutrazol. By 6 WAT, plants treated with the highest rate of paclobutrazol and flurprimidol had lower dry weights and higher chlorophyll measurements than control. All PGR treatments for Expt. 2 resulted in smaller plants than the control by $27 \%$ to $36 \%$ at 4 WAT and $23 \%$ to $41 \%$ at 6 WAT. Differences for internode length and flower diameter were observed for Expts. 1 and 2 , respectively. Results from these experiments suggest a substrate drench application of $6 \mathrm{mg}$ /pot paclobutrazol or $4 \mathrm{mg} /$ pot flurprimidol can be used for producing smaller plants compared with nontreated plants for swamp sunflower under greenhouse conditions.

S wamp sunflower is an underused, fall-blooming southern United States native perennial plant producing a swath of eye-catching inflorescences. The numerous flower heads reside above the foliage in a corymbose or racemose arrangement, each with a medium-sized disk of 1.3 to $2 \mathrm{~cm}$ diameter. A member of the Asteraceae family, it has 12 to 23 golden-yellow ray florets surrounding the central disk florets with dark purplish-red corollas (Flora of North

Received for publication 8 May 2019. Accepted for publication 29 July 2019.

Published online 17 September 2019

${ }^{1}$ Department of Horticulture, University of Georgia, 1111 Miller Plant Science, Athens, GA 30602

K.B. is a PhD candidate.

J.M.R. is an Armitage Endowed Professor of Horticulture.

K.B. is the corresponding author. E-mail: kbarrios25@uga.edu.

This is an open access article distributed under the $\mathrm{CC}$ BY-NC-ND license (https://creativecommons.org/ licenses/by-nc-nd/4.0/).

https://doi.org/10.21273/HORTTECH04400-19
America, 2006; Heiser et al., 1969; Watson, 1929). The plant typically grows $\approx 1.0$ to $1.8 \mathrm{~m}$ tall but can reach $2.5 \mathrm{~m}$ in height. Swamp sunflower's native range is from Georgia west to Texas and Arkansas southward to the Gulf Coast into southern Florida. Other common names, such as muck sunflower, suggest it is typically found in moist or saturated soils near ponds, riparian areas, and drainage ways. As a facultative wetland plant, this species can be found in nonwetland habitats [The Wildlife Center (TWC), 2008; Wunderlin et al., 2019]. The plant grows best in full sun to partial shade and tolerates a variety of growing conditions, reportedly staying more compact in denser, saturated soils (TWC, 2008). In addition to aesthetics, the flowers and seeds are valuable to wildlife such as native bees and birds (TWC, 2008 ). With the growing interest in using natives as ornamentals, swamp sunflower is a strong candidate for wider use in perennial beds and landscapes, and research on nursery and shipping protocols could result in wider production and landscape use.

To ship and sell plants feasibly and economically, their size and shape need to be kept within certain dimensions while retaining aesthetic characteristics. This can be accomplished by pruning or pinching plants, yet this is labor-intensive and costly, particularly for vigorous plants. A less labor-intensive and widely used method to control growth and branching in commercial environments is the use of plant growth regulators (Whipker, 2013). Plant growth retardants, a subgroup of PGRs, commonly inhibit biosynthesis of the plant hormone gibberellin, thereby restricting plant growth (Davis et al., 1988; Rademacher, 2000). The most widely used PGR in the United States to control excessive growth in greenhouse-grown floricultural crops is the plant growth retardant paclobutrazol (Rademacher, 2000; Whipker, 2013). Restrictions in height of annual sunflower (Helianthus annuus) in response to paclobutrazol and other PGRs have been demonstrated (Ahmad et al., 2015; Barbosa et al., 2008; Dasoju et al.,

\begin{tabular}{llll}
\hline $\begin{array}{l}\text { Units } \\
\text { To convert U.S. to SI, } \\
\text { multiply by }\end{array}$ & U.S. unit & SI unit & $\begin{array}{l}\text { To convert SI to U.S., } \\
\text { multiply by }\end{array}$ \\
\hline 29.5735 & $\mathrm{fl} \mathrm{oz}$ & $\mathrm{mL}$ & 0.0338 \\
0.3048 & $\mathrm{ft}$ & $\mathrm{m}$ & 3.2808 \\
0.0283 & $\mathrm{ft}^{3}$ & $\mathrm{~m}^{3}$ & 35.3147 \\
3.7854 & $\mathrm{gal}$ & $\mathrm{L}$ & 0.2642 \\
2.54 & inch(es) & $\mathrm{cm}^{2}$ & 0.3937 \\
6.4516 & inch & $\mathrm{cm}^{2}$ & 0.1550 \\
593.2764 & $\mathrm{lb} / \mathrm{yard}^{3}$ & $\mathrm{~g} \cdot \mathrm{m}^{-3}$ & 0.0017 \\
28.3495 & $\mathrm{oz}$ & $\mathrm{g}$ & 0.0353 \\
28,350 & $\mathrm{Oz}$ & $\mathrm{mg}$ & $3.5274 \times 10^{-5}$ \\
0.001 & $\mathrm{ppm}$ & $\mathrm{g} \cdot \mathrm{L}^{-1}$ & 1000 \\
1 & $\mathrm{ppm}$ & $\mathrm{mg} \cdot \mathrm{L}^{-1}$ & 1 \\
$\left({ }^{\circ} \mathrm{F}-32\right) \div 1.8$ & ${ }^{\circ} \mathrm{F}$ & ${ }^{\circ} \mathrm{C}$ & $\left({ }^{\circ} \mathrm{C} \times 1.8\right)+32$ \\
& & &
\end{tabular}


1998; Koutroubas et al., 2014; Vernieri et al., 2003; Whipker and Latimer, 2016; Whipker and McCall, 2000). The rate of paclobutrazol has been evaluated on potted sunflower in previous studies, for example, with Dasoju et al. (1998) finding paclobutrazol at $2 \mathrm{mg} /$ pot as a substrate drench on potted sunflower 'Pacino' reduced height by $17 \%$ to $25 \%$. Similar responses from a similar application of paclobutrazol were obtained by Whipker and McCall (2000) on five cultivars of annual sunflower. Whipker and McCall (2000) and Ahmad et al. (2015) determined that $4 \mathrm{mg} / \mathrm{pot}$ effectively reduced growth of 'Pacino Gold'. Barbosa et al. (2008) observed reduced plant height with increased paclobutrazol concentration and recommended $6 \mathrm{mg} /$ pot for the annual sunflower 'Golden'. Dasoju et al. (1998) tested a wide range of rates with reductions in plant height and diameter up to $16 \mathrm{mg} /$ pot but observed phytotoxicity at 16 and $32 \mathrm{mg} /$ pot. Insufficient height reduction by paclobutrazol on potted sunflower was reported by Whipker and Dasoju (1998) when applied as a foliar spray and suggested spraying at even higher concentrations (>80 mg/pot) or using a substrate drench application. A 2 to $3 \mathrm{ppm}$ substrate drench application of paclobutrazol 1 to 2 weeks after pinching during greenhouse production is suggested for an interspecific hybrid sunflower [Helianthus bybrida 'Sunfinity' (Syngenta Flowers, 2017)]. The application method of paclobutrazol in precedent literature has largely been by foliar spray or substrate drench with more favorable results from the use of substrate drenches (Hawkins et al., 2015; Keever et al., 1990; Whipker and Dasoju, 1998). Recommendations for greenhouse floriculture growers advise the application of paclobutrazol as a high-rate substrate drench for enduring effects throughout the growing season. For sunflower, the recommended application is a 2 - to 4-mg substrate drench of $4 \mathrm{fl} \mathrm{oz}$ per 6-inch pot (Whipker, 2013).

Flurprimidol is another popular plant growth retardant for ornamentals that inhibits the biosynthesis of gibberellin and has restricted plant height and diameter of potted 'Pacino' annual sunflower when applied as a substrate drench or foliar spray (Whipker, 2013; Whipker et al.,
2004). Whipker et al. (2004) compared two PGRs to flurprimidol and found results from a $2 \mathrm{mg} /$ pot substrate drench application of flurprimidol to be similar to those of paclobutrazol. Another comparison by Vernieri et al. (2003) found flurprimidol at $60 \mathrm{mg} \cdot \mathrm{L}^{-1}$ applied as a foliar spray on sunflower was less effective on height reduction than a low dose of paclobutrazol $(2 \mathrm{mg}$ / pot) applied as a substrate drench. Application of flurprimidol in other species as a drench rather than spray has been shown to produce more ideal plant effects, including reduction in plant size, while not affecting flowering time or flower size (Krug et al., 2005a, 2005b; Rezazadeh and Harkess, 2015; Whipker et al., 2006).

The objective of this study was to evaluate the effects of two common plant growth retardants, paclobutrazol and flurprimidol, applied as substrate drenches on the growth and flowering of swamp sunflower.

\section{Materials and methods}

ExPT. 1. Subterminal cuttings of three to four nodes were taken 10 Apr. 2018 from clonal material of swamp sunflower from a stock plant at the University of Georgia's (UGA) Durham Horticulture Farm in Watkinsville. Cuttings were dipped in a fungicide solution of $15.58 \mathrm{~g} \cdot \mathrm{L}^{-1}$ azoxystrobin (Abound; Syngenta Crop Protection, Greensboro, NC) for 10 to $15 \mathrm{~s}$ before sticking in propagation substrate in 1020 trays $(21.2 \times 10.8 \times 2.3$ inches; Landmark Plastic, Akron, OH). Propagation substrate was wet 1 to $2 \mathrm{~d}$ before sticking cuttings and consisted of 2 potting mix: 1 perlite (by volume). Potting mix used was Jolly Gardener Proline C/L Growing Mix (Oldcastle, Shady Dale, GA) and was amended with micronutrients (Micromax; Everris NA, Dublin, $\mathrm{OH}$ ) at $1.00 \mathrm{lb} /$ yard $^{3}$. After cuttings were stuck, a humidity dome was placed over the tray, placed under mist ( $8 \mathrm{~s}$ every $5 \mathrm{~min}$ from 7:00 AM to 7:00 PM), and covered by shadecloth $(50 \%$ exclusion) under greenhouse conditions. After $30 \mathrm{~d}$, rooted cuttings were removed from trays and placed in 4-inch (height) square pots (Kord; The HC Companies, Twinsburg, $\mathrm{OH}$ ) filled with potting substrate (Promix BX Mycorrhizea; Premier Tech Horticulture, Rivière-du-Loup, QC, Canada) amended with same micronutrients as above. Rooted cuttings were placed in a shaded area in greenhouse, watered as needed, and fertilized weekly with a $20 \mathrm{~N}-$ $4.4 \mathrm{P}-16.6 \mathrm{~K}$ water-soluble liquid fertilizer at $200 \mathrm{mg} \cdot \mathrm{L}^{-1}$ nitrogen (Jack's Professional; J.R. Peters, Allentown, $\mathrm{PA})$. After $\approx 16 \mathrm{~d}$, rooted cuttings were moved to an unshaded area of polyethylene greenhouse and continued to grow for $\approx 1$ week. Rooted cuttings were then transplanted to l-gal pots filled with potting substrate (pine bark, peat, and sand mix; Oldcastle) and top-dressed with a $16 \mathrm{~N}-2.6 \mathrm{P}-10.0 \mathrm{~K}$ controlled-release fertilizer at $10 \mathrm{~g} / \mathrm{pot}$ (Harrell's Polyon, Lakeland, FL). Plants were transferred on the same day to a polycarbonate greenhouse at the UGA Trial Gardens in Athens, GA, and allowed to grow before initiating the experiment. Plants were cut back for uniformity ( $\approx 15$ to $20 \mathrm{~cm}$ from the substrate) on 21 May 2018. Fans in the greenhouse were programmed to vent when internal temperature $\geq 27^{\circ} \mathrm{C}$ day and night; however, daytime temperatures in the summer often exceeded $32^{\circ} \mathrm{C}$ within the greenhouse. The experiment was a completely randomized design with 12 replicates per treatment level in which a replicate was a single plant in a l-gal pot and pots were spaced $\approx 18$ inches apart.

Four days before application, plants were cut back to two nodes/ stem. The evening (6:00 PM) before treatment application, plants were watered to container capacity. Treatments were applied 25 June 2018 beginning at 8:15 $\mathrm{Am}$ as a $120-\mathrm{mL}$ substrate drench of paclobutrazol (Piccolo 10 XC; Fine Americas, Walnut Creek, CA), flurprimidol (Topflor; SePRO, Carmel, IN), or municipal water (control). PGR treatment was delivered as $1.0,2.0,4.0$, or $6.0 \mathrm{mg} /$ pot paclobutrazol or $0.5,1.0,2.0$, or $4.0 \mathrm{mg} /$ pot flurprimidol. Plants were hand watered as needed and fertigated once weekly with liquid fertilizer at 200 $\mathrm{mg} \cdot \mathrm{L}^{-1}$ nitrogen $(20 \mathrm{~N}-4.4 \mathrm{P}-16.6 \mathrm{~K}$, Jack's Professional). The experiment ended at 6 WAT (6 Aug. 2018).

Plant height and width measurements were taken the day following treatment application (Day 1) and 2, 4 , and 6 WAT. Plant height was measured from the surface of the substrate to the highest point of the plant. Width was the average of the two widest perpendicular dimensions. Height and width increases 
Table 1. Expt. 1 data of final height decrease as percent of the control, dry weight, and chlorophyll meter measurements of swamp sunflower plants 6 weeks after treated with a plant growth regulator or control on 25 June 2018.

\begin{tabular}{llccc}
\hline $\begin{array}{l}\text { Treatment } \\
(\mathbf{m g} / \text { pot })^{\mathrm{z}}\end{array}$ & $\begin{array}{c}\text { Final ht decrease } \\
(\% \text { control })^{\mathrm{y}}\end{array}$ & Dry wt $(\mathbf{g})^{\mathrm{z}}$ & $\begin{array}{c}\text { Chlorophyll meter } \\
\text { measurements }\end{array}$ \\
\hline Control & & & $66.3 \mathrm{a}$ & $32.6 \mathrm{c}$ \\
Paclobutrazol & 1 & $2.8 \mathrm{c}^{\mathrm{x}}$ & $65.4 \mathrm{ab}$ & $32.8 \mathrm{c}$ \\
& 2 & $3.8 \mathrm{c}$ & $61.1 \mathrm{abc}$ & $34.0 \mathrm{c}$ \\
& 4 & $27.0 \mathrm{~b}$ & $54.7 \mathrm{~cd}$ & $35.6 \mathrm{bc}$ \\
Flurprimidol & 6 & $35.6 \mathrm{ab}$ & $49.4 \mathrm{de}$ & $39.4 \mathrm{a}$ \\
& 0.5 & $6.1 \mathrm{c}$ & $61.2 \mathrm{abc}$ & $32.5 \mathrm{c}$ \\
& 1 & $9.1 \mathrm{c}$ & $58.5 \mathrm{bc}$ & $33.9 \mathrm{c}$ \\
Significance & 2 & $19.5 \mathrm{bc}$ & $55.7 \mathrm{c}$ & $34.5 \mathrm{c}$ \\
& 4 & $46.5 \mathrm{a}$ & $46.1 \mathrm{e}$ & $38.2 \mathrm{ab}$ \\
\hline
\end{tabular}

${ }^{\mathrm{z}} 1 \mathrm{mg}=3.5274 \times 10^{-5} \mathrm{oz}, 1 \mathrm{~g}=0.0353 \mathrm{oz}$.

${ }^{\mathrm{y}}$ Final height decrease as percent of control $=\{1-[$ (height 6 weeks after treatment - height on day immediately after treatment application $) \div$ average height increase of control $]\} \times 100$.

${ }^{\mathrm{x}}$ Means separations (in columns) by all pairwise comparison tests with Bonferroni adjustment $P \leq 0.05$ (lowercase letters). Treatment levels within columns having the same letter are not significantly different.

$* * *$ indicates significance at $P \leq 0.001(\mathrm{n}=12)$.

\section{$\square$ Control $\square$ Pac-1 $\square$ Pac-2 $\square$ Pac-4 $\square$ Pac-6 $\square$ Flur-0.5 $\square$ Flur-1 $\square$ Flur-2 $\square$ Flur-4}

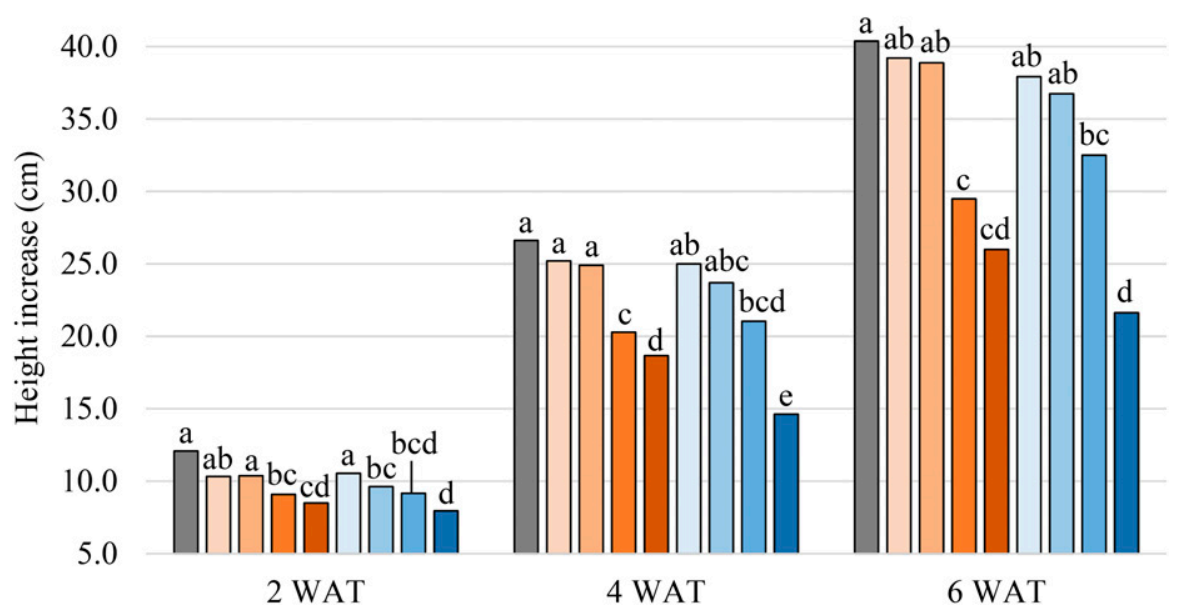

Fig. 1. Effects of the plant growth regulators (PGRs) flurprimidol (Flur) and paclobutrazol (Pac) substrate drenches (milligrams/pot) on the height increases of container-grown swamp sunflower at 2, 4, and 6 weeks after treatment (WAT) for Expt. 1 (initiated 25 June 2018). Control had no PGR applied. Height increase $=$ (height at week 2,4 , or 6 - height on day after treatment application). Analysis of variance was conducted for each week of data collection $[P \leq 0.05(n=$ 12)]. Means separation by pairwise comparison tests with Bonferroni adjustment $P \leq 0.05$ (lowercase letters) at each week of data collection. Treatment levels within week having the same letter are not significantly different; $1 \mathrm{mg}=3.5274 \times 10^{-5}$ oz, $1 \mathrm{~cm}=0.3937$ inch.

were calculated by subtracting the initial plant height or width measured on Day 1 from the height or width at the week of data collection. Growth index (GI) was calculated as height $\times$ widthl $\times$ width2 to reflect overall plant volume in cubic centimeters and increases were calculated as differences from Day l to a specific week of data collection. Chlorophyll meter (SPAD-502; Minolta Camera Corp., before the termination of the experiment. Internode length was taken by averaging the lengths between the second and third node from the apex of three random stems per plant.

ExpT. 2. Plants were obtained using the method outlined earlier and the experiment was conducted in the same location as described in Expt. 1. Cuttings were taken 3 June 2018 , allowed to root in 1020 trays $(21.2 \times 10.8 \times 2.3$ inches, Landmark Plastic), and transplanted to 4 inch square pots (Kord, The HC Companies) 28 d after sticking. Rooted cuttings were then transplanted to $\mathrm{l}$-gal pots after $24 \mathrm{~d}$ and brought to the UGA Trial Gardens in Athens, GA. Plants were cut back for uniformity $26 \mathrm{~d}$ before treatment (12 Aug. 2018). Greenhouse temperatures were maintained similar to Expt. 1, and beginning 22 Oct., heat was provided to maintain internal greenhouse temperatures at $\geq 24{ }^{\circ} \mathrm{C}$ day/ $\approx 18{ }^{\circ} \mathrm{C}$ night. Experimental design and setup were the same as Expt. I with one less treatment level for each PGR. Rates of PGRs for Expt. 2 were adjusted based on results from Expt. 1 and treatments were applied 7 Sept. 2018 using the same method as Expt. 1. Treatment was $4.0,6.0$, or 8.0 $\mathrm{mg}$ /pot paclobutrazol or $2.0,4.0$, or $6.0 \mathrm{mg} /$ pot flurprimidol. The experiment was ended at 8 WAT (2 Nov. 2018), 2 weeks longer than Expt. 1 to allow for flowering observations.

Height and width measurements were taken identical to Expt. I with an additional measurement of height at 8 WAT. Chlorophyll meter readings and dry weight were also measured identically to Expt. 1. Internode length for Expt. 2 was not measured due to the development of inflorescences.

Floral data were collected for Expt. 2 (but not Expt. 1), since it blooms in the fall (August to November) (Flora of North America, 2006; TWC, 2008). At termination (8 WAT), the number of flowers and buds was counted to obtain the total flower count. Flower diameter (to nearest $0.25 \mathrm{~cm}$ ) was measured, and the number of ray florets was counted on three random mature flowers for each plant; a mature flower was one with disc florets at anthesis. Eleven plants were used per treatment for flower diameter and ray floret number 

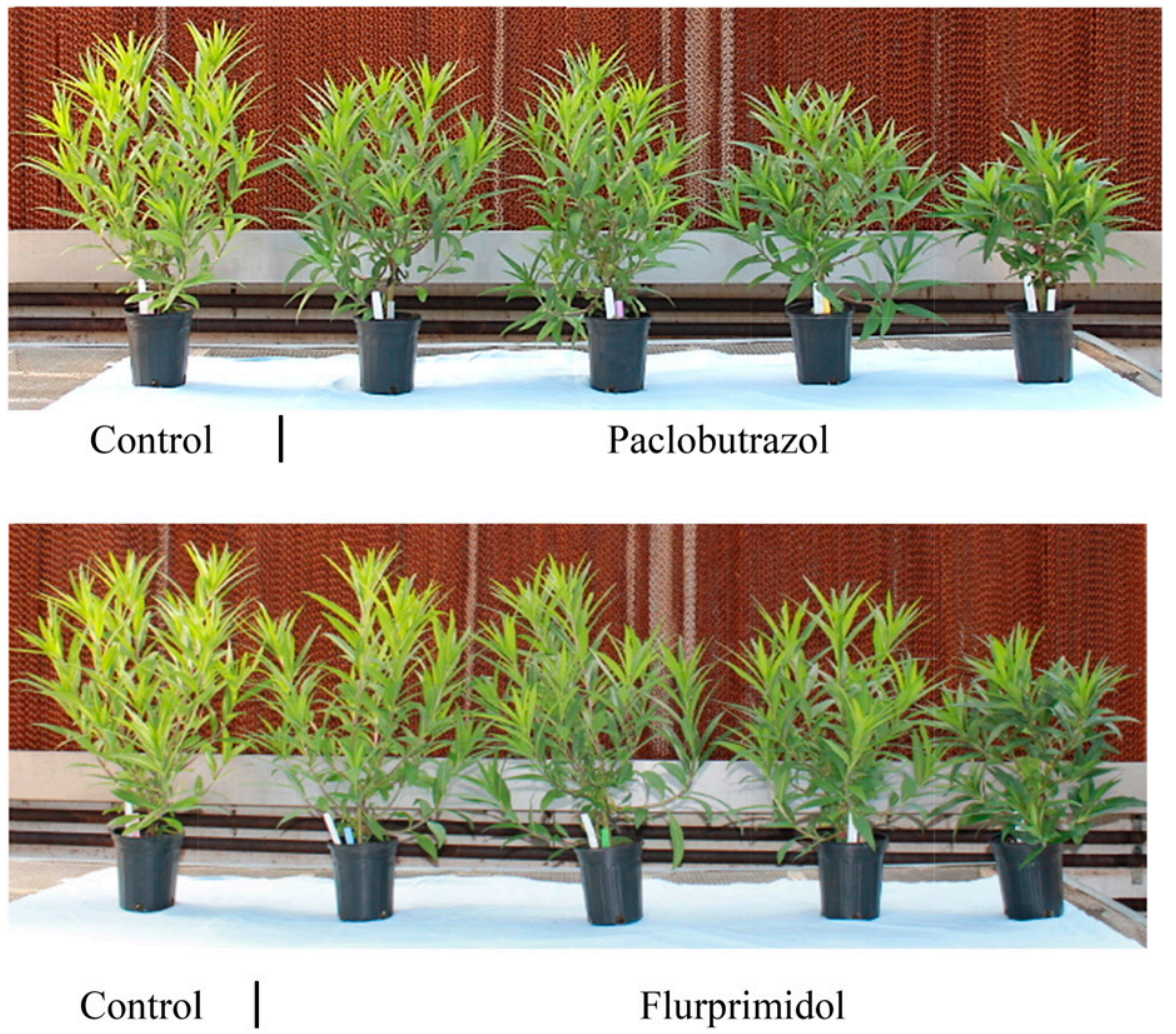

Fig. 2. Effect of the plant growth regulators (PGRs) paclobutrazol and flurprimidol substrate drenches on the growth of container-grown swamp sunflower at 6 weeks after PGR application for Expt. 1 (initiated 25 June 2018). Control had no PGR applied. Paclobutrazol rates were 1, 2, 4, and $6 \mathrm{mg} /$ pot (leftright) and flurprimidol rates applied were $0.5,1,2$, and $4 \mathrm{mg} /$ pot (left-right); $1 \mathrm{mg}=3.5274 \times 10^{-5}$.

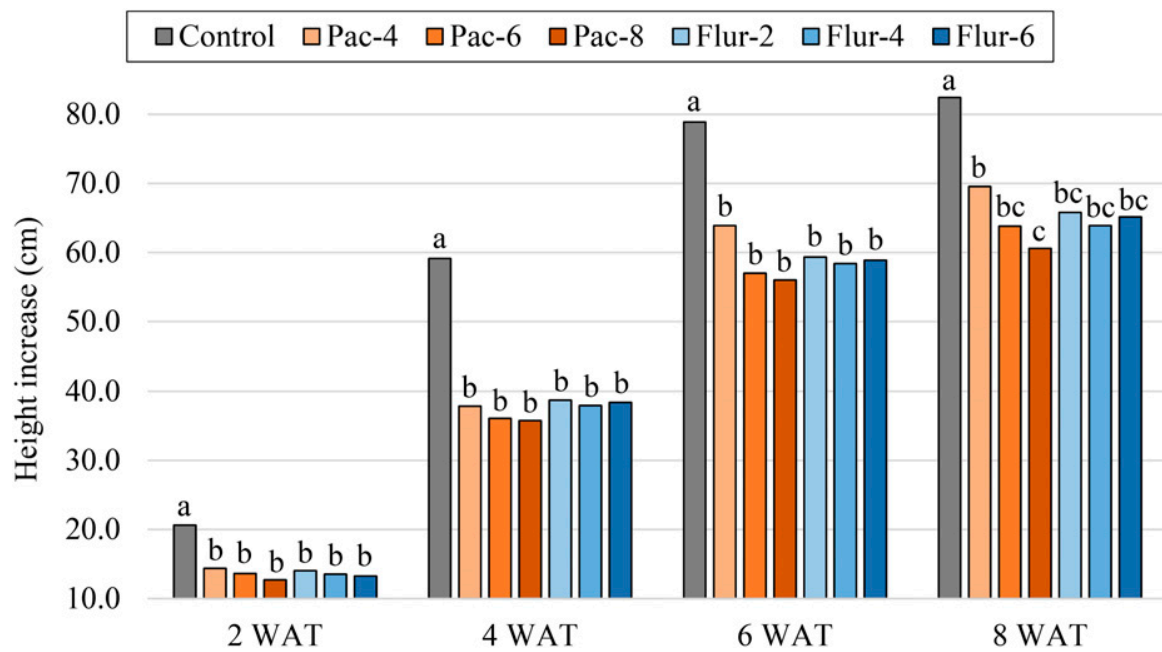

Fig. 3. Effects of the plant growth regulators (PGRs) flurprimidol (Flur) and paclobutrazol (Pac) substrate drenches (milligrams/pot) on the height increases of container-grown swamp sunflower at 2, 4, 6, and 8 weeks after treatment (WAT) for Expt. 2 (initiated 7 Sept. 2018). Control had no PGR applied. Height increase $=$ (height at week $2,4,6$, or 8 - height on day after treatment application $)$. Analysis of variance was conducted for each week of data collection $(P \leq 0.05, n=$ 12). Means separation by pairwise comparison tests with Bonferroni adjustment $P \leq 0.05$ (lowercase letters) at each week of data collection. Treatment levels within week having the same letter are not significantly different; $1 \mathrm{mg}=3.5274 \times 10^{-5}$, $1 \mathrm{~cm}=0.3937$ inch. per flower because not all plants had three mature flowers. Flower timing data were taken for the date of first visible yellow ray floret, date of the first opened flower and the date of full flower. An opened flower had ray florets at $\approx 60^{\circ}$ from the center of the head, and a plant was in full flower when at least $80 \%$ of flowers were opened.

Data analysis. Data for both experiments were analyzed by a oneway analysis of variance for each week of collection to obtain significance, and means comparisons of treatment levels were analyzed with the Bonferroni adjustment $(P \leq 0.05)$ in the $\mathrm{R}$ program (R Core Team, 2016).

\section{Results}

EXPT. 1. Application of paclobutrazol and flurprimidol as substrate drenches at the specified rates affected plant height and width, dry weight, and chlorophyll meter measurements of swamp sunflower (Table 1; Figs. 1-3). Height increase was less than the control for plants treated with the two highest rates of paclobutrazol and flurprimidol at 2, 4, and 6 WAT (Table 1; Fig. 1). Reductions in height increase of plants treated with the aforementioned PGR rates compared with the control were $21 \%$ to $45 \%$ at 4 WAT and $19 \%$ to $46 \%$ at 6 WAT. For flurprimidol, plants receiving $1.0 \mathrm{mg} /$ pot were shorter than the control at 2 WAT (Fig. 1). Among PGR rates, the two highest rates of paclobutrazol and the highest rate of flurprimidol restricted plant height at 6 WAT compared with other PGR rates by at least $20 \%$, with the exception of flurprimidol at $2.0 \mathrm{mg} /$ pot. Similar differences in height increase among PGR applications at 6 WAT were observed at 4 WAT with the highest rate of flurprimidol having a minimum of $22 \%$ height restriction.

Increase in plant width was reduced from the control by application of the highest rate of paclobutrazol and the two highest rates of flurprimidol at 2, 4, and 6 WAT (Fig. 4). At the termination of the study (6 WAT), the two highest PGR rates, paclobutrazol at $6.0 \mathrm{mg} /$ pot and flurprimidol at $4.0 \mathrm{mg} / \mathrm{pot}$, restricted plant width compared with flurprimidol at $1.0 \mathrm{mg} /$ pot by $10 \%$ and $18 \%$, respectively. Similar differences were observed between the lowest and highest rates of PGRs at 2 and 4 


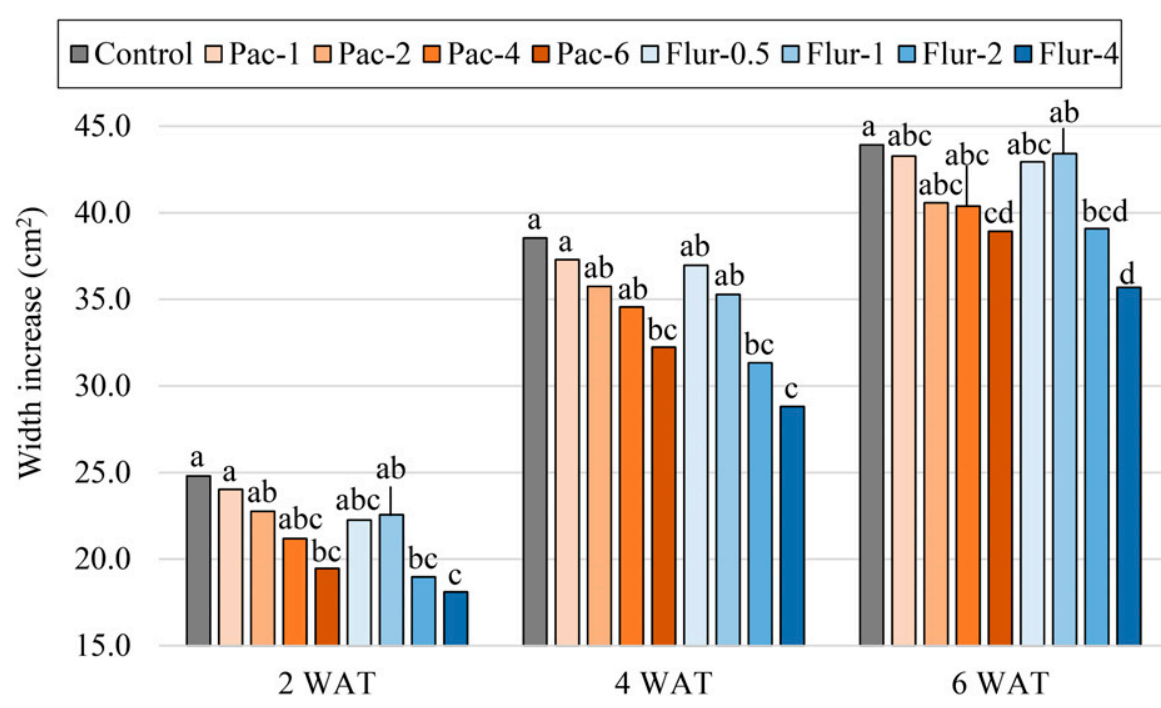

Fig. 4. Effects of the plant growth regulators (PGRs) flurprimidol (Flur) and paclobutrazol (Pac) substrate drenches (milligrams/pot) on the width (width $1 \times$ width 2 ) increases of container-grown swamp sunflower at 2,4 , and 6 weeks after treatment (WAT) for Expt. 1 (initiated 25 June 2018). Control had no PGR applied. Width increase $=($ width at week 2,4 , or 6 - width on day after treatment application). Analysis of variance was conducted for each week of data collection $(P \leq 0.05, \mathrm{n}=12)$. Means separation by pairwise comparison tests with Bonferroni adjustment $P \leq 0.05$ (lowercase letters) at each week of data collection. Treatment levels within week having the same letter are not significantly different; $1 \mathrm{mg}=$ $3.5274 \times 10^{-5}, 1 \mathrm{~cm}^{2}=0.1550$ inch $^{2}$.

WAT (Fig. 4). At 4 WAT, application of the highest rate of flurprimidol restricted width growth by $18 \%$ to $23 \%$ from the two lowest rates of both PGRs. Among paclobutrazol rates at 4 WAT, plants treated with the highest paclobutrazol rate were $13 \%$ narrower than the lowest paclobutrazol rate.

Growth index was affected by PGR application at 2 and 4 WAT. Plants treated with the two highest rates of paclobutrazol and all but the lowest rate of flurprimidol were smaller than the control by $18 \%$ to $50 \%$ at 2 and 4 WAT (data not shown). After 2 weeks of growth, application of paclobutrazol at the two highest rates restricted growth compared with the lowest paclobutrazol rate, and the application of the highest rate of flurprimidol restricted growth compared with the two lowest flurprimidol rates. After 4 weeks, the highest rate of flurprimidol produced smaller plants than other PGR treatments, with the exception of the highest rate of paclobutrazol. At termination (6 WAT), the two highest rates of each PGR yielded smaller plants than the control by $22 \%$ to $48 \%$ (Table 2). Furthermore, plants treated with the two highest rates of paclobutrazol were smaller than those respectively, at 6 WAT $(P \leq 0.0 \mathrm{l})$ compared with the lowest rate of flurprimidol (data not shown).

Expт. 2. Application of paclobutrazol and flurprimidol as substrate drenches at the specified rates affected increase in plant height and width and flower diameter of swamp sunflower (Table 3; Figs. 3 and 5). All PGR application rates resulted in shorter plants than the control at each week of data collection, with the greatest reductions occurring $4 \mathrm{WAT}$ [34\% to $40 \%$ (Fig. 3)]. After 8 weeks of growth, plants treated with the highest concentration of paclobutrazol $(8.0 \mathrm{mg} / \mathrm{pot})$ were shorter than plants treated with half that concentration $(4.0 \mathrm{mg} /$ pot $)$, but no other differences of height increase among PGR treatments were observed (Table 3; Fig. 3).

The application of paclobutrazol at 6.0 and $8.0 \mathrm{mg} /$ pot restricted the increase in plant width at 6 WAT compared with the control by $29 \%$ and $26 \%$, respectively (Table 3 ). Increase in plant width at 2 and 4 WAT was not influenced by PGR treatment (data not shown).

Growth index was affected by butrazol by $28 \%$ and $33 \%$, and the highest rate of flurprimidol resulted in smaller plants than all PGR treatments by at least $27 \%$, with the exception of the highest rate of paclobutrazol.

Dry weight of plants treated with the two highest rates of paclobutrazol and all but the lowest rate of flurprimidol was restricted by $12 \%$ to $30 \%$ compared with the control (Table 1). The highest rate of flurprimidol resulted in plants with the lowest dry weight of all treatments, apart from the highest paclobutrazol rate. The two highest concentrations of paclobutrazol resulted in plants with $16 \%$ and $24 \%$ lower dry weights than the lowest concentration of paclobutrazol. Similarly, the highest concentration of flurprimidol resulted in plants with $17 \%$ to $25 \%$ lower dry weights than other rates of flurprimidol.

The highest rate of paclobutrazol had the highest chlorophyll meter measurement of all treatments (with a $17 \%$ increase from the control), apart from the highest rate of flurprimidol that had a $15 \%$ increase from the control (Table 1 ).

The highest rate of paclobutrazol and flurprimidol had shorter internode lengths by 1.2 and $1.4 \mathrm{~cm}$,
PGR treatment at each week of data collection (6 WAT growth index shown in Table 2). The highest rate of flurprimidol and the two highest rates of paclobutrazol yielded smaller plants than the control by $35 \%$ to $40 \%$ at 2 WAT (data not shown). All PGR treatments yielded smaller plants than the control by $27 \%$ to $36 \%$ at 4 WAT and $23 \%$ to $41 \%$ at 6 WAT [Table 2 (data not shown for 4 WAT)].

Treatment effect on dry weight was not found to be significant (data not shown). Chlorophyll meter measurements were not different among treatments when measured at 8 WAT (data not shown).

The diameter of mature flowers (Table 3 ) and the number of flowers and flower buds per plant $(P=0.041)$, when measured or counted 8 WAT, were affected by PGR treatments. The diameter of flowers on plants treated with flurprimidol at $6.0 \mathrm{mg} /$ pot was $7 \%$ wider than plants treated with paclobutrazol at the same rate (Table 3). The number of flowers and flower buds per plant ranged from 95 to 115 , and although treatment was found to have an effect on this parameter, no differences between treatment levels were found using 
Table 2. Volumetric growth increases for plants of swamp sunflower treated with plant growth regulator (PGR) or control on 25 June 2018 (Expt. 1) or 7 Sept. 2018 (Expt. 2).

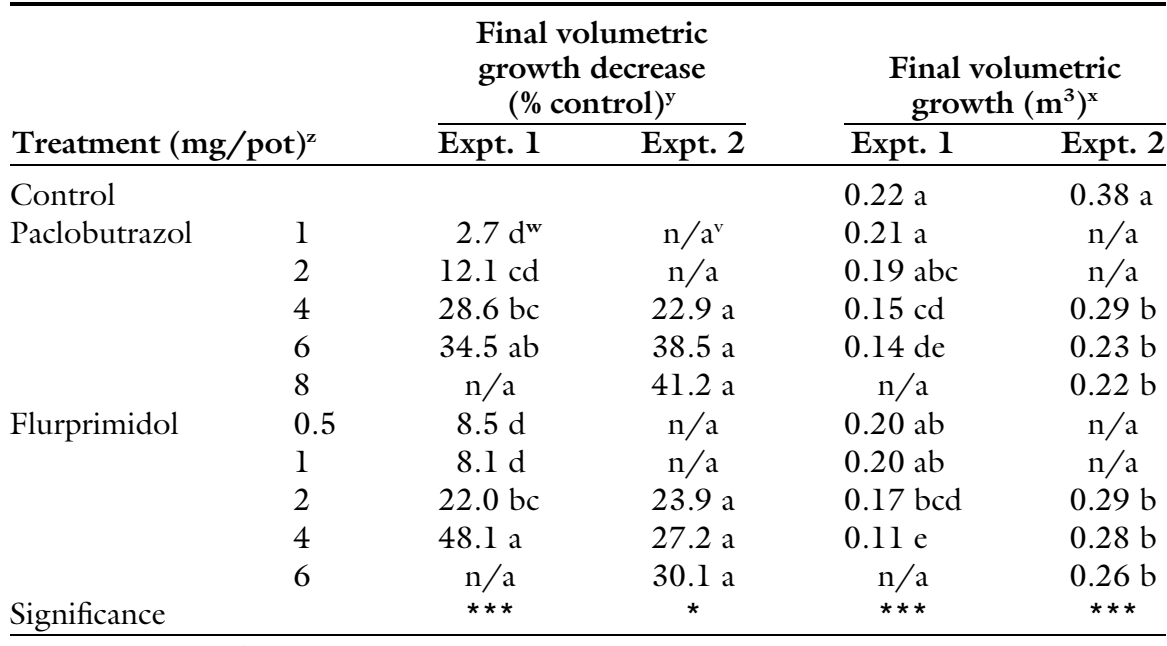

${ }^{\mathrm{z}} 1 \mathrm{mg}=3.5274 \times 10^{-5} \mathrm{oz}$.

${ }^{y}$ Final volumetric growth decrease as percent of control $=\{1-[$ (volume 6 weeks after treatment - volume on day immediately after treatment application $) \div$ average volume increase of control $]\} \times 100$, where volume $=($ height $\times$ width $\times$ width $)$.

${ }^{\mathrm{x}}$ Final volumetric growth $=$ (volume 6 weeks after treatment - volume on day immediately after treatment application); $1 \mathrm{~m}^{3}=35.3147 \mathrm{ft}^{3}$.

${ }^{w}$ Means separations (in columns) by all pairwise comparison tests with Bonferroni adjustment $P \leq 0.05$ (lowercase letters). Treatment levels within column having the same letter are not significantly different.

${ }^{\mathrm{V}}$ Indicates no PGR was applied at a specific rate for a particular experiment.

$* * *, *$ indicate significance at $P \leq 0.001$ or 0.05 , respectively $(\mathrm{n}=12)$

Table 3. Expt. 2 data of final height increase as percent of control, width, and flower diameter of swamp sunflower plants treated with plant growth regulator or control on 7 Sept. 2018.

\begin{tabular}{lcccc}
\hline $\begin{array}{l}\text { Treatment } \\
(\mathbf{m g} / \text { pot })^{\mathbf{z}}\end{array}$ & $\begin{array}{c}\text { Final ht decrease } \\
(\% \text { control })^{\mathbf{y}}\end{array}$ & $\begin{array}{c}\text { Final width } \\
\text { increase }\left(\mathbf{c m}^{2}\right)^{\mathbf{x}}\end{array}$ & Flower diam $(\mathbf{c m})^{\mathbf{w}}$ \\
\hline Control & & & $29.8 \mathrm{a}$ & $9.8 \mathrm{ab}$ \\
Paclobutrazol & 4 & $15.7^{\mathrm{v}}$ & $27.5 \mathrm{ab}$ & $10.3 \mathrm{ab}$ \\
& 6 & 22.6 & $21.0 \mathrm{~b}$ & $9.7 \mathrm{~b}$ \\
& 8 & 26.5 & $21.9 \mathrm{~b}$ & $9.9 \mathrm{ab}$ \\
Flurprimidol & 2 & 20.2 & $26.7 \mathrm{ab}$ & $10.1 \mathrm{ab}$ \\
& 4 & 22.5 & $27.4 \mathrm{ab}$ & $10.2 \mathrm{ab}$ \\
& 6 & 21.0 & $25.1 \mathrm{ab}$ & $10.4 \mathrm{a}$ \\
Significance & & NS & $* *$ & $*$
\end{tabular}

${ }^{\mathrm{z}} 1 \mathrm{mg}=3.5274 \times 10^{-5} \mathrm{oz}$.

${ }^{\mathrm{y}}$ Final height decrease as percent of control $=\{1-[$ (height 8 weeks after treatment - height on day immediately after treatment application $) \div$ average height increase of control $]\} \times 100$.

${ }^{v}$ Means separations (in columns) by pairwise comparison tests with Bonferroni adjustment $P \leq 0.05$ (lowercase letters). Treatment levels within columns having the same letter are not significantly different.

${ }^{x}$ Final width increase $=($ width 6 weeks after treatment - width on day immediately after treatment application $)$, where width $=[($ width $1 \times$ width 2$) \div 2] ; 1 \mathrm{~cm}^{2}=0.1550 \mathrm{~cm}^{2}$

${ }^{\mathrm{w}}$ Flower diameter measured 8 weeks after treatment application and is the average of three mature flowers per plant, where a mature flower had disc florets that had reached anthesis; $1 \mathrm{~cm}=0.3937 \mathrm{inch}$.

$\mathrm{Ns},{ }^{* *},{ }^{* *},{ }^{*}$ indicate nonsignificance or significance at $P \leq 0.001,0.01$, or 0.05 , respectively $(\mathrm{n}=12)$.

pairwise comparison tests (data not shown). The number of ray florets per mature flower, which ranged from 13 to 15 , was unaffected by treatment (data not shown). The number of days to first visible yellow of ray florets, first fully open flower, and full flower from the day of treatment application were unaffected by treatment (data not shown). The means of the number of days to first visible yellow florets $( \pm$ SE) were $33.9 \pm 1.1$ for the control; $36.6,36.4$, and $35.9 \pm$ 1.1 in ascending order by the rate for paclobutrazol; and 35.8, 36.7, and $37.2 \pm 1.1$ in ascending order by rate for flurprimidol. The means of the number of days to first full flower $( \pm$ SE) were: $37.8 \pm 1.3$ for the control; $40.6,40.0$, and $39.7 \pm 1.3$ in ascending order by rate for paclobutrazol; and $39.4,40.4$, and $40.9 \pm 1.3$ in ascending order by rate for flurprimidol. The means of the number of days to full flower $( \pm \mathrm{SE})$ were $50.8 \pm 2.2$ for the control; $57.2,55.3$, and $53.7 \pm$ 2.2 in ascending order by rate for paclobutrazol; and 54.8, 55.0, and $55.8 \pm 2.2$ in ascending order by rate for flurprimidol.

\section{Discussion}

Restrictions of plant height from the control that were observed in Expts. 1 and 2 for paclobutrazol and flurprimidol are similar to previous studies. After 6 weeks for Expt. 1 and 4 WAT for Expt. 2, plants treated with paclobutrazol at 4.0 $\mathrm{mg} /$ pot had $27 \%$ and $36 \%$ reductions in height growth, respectively, compared with the control. Similar results with a substrate drench application of $4 \mathrm{mg} /$ pot paclobutrazol were observed as $26 \%$ to $36 \%$ shorter plants than the control by Dasoju et al. (1998), Whipker and McCall (2000), and Ahmad et al. (2015) for potted annual sunflower. Although previous studies observed $20 \%$ to $27 \%$ shorter plants with a $2 \mathrm{mg} / \mathrm{pot}$ drench of paclobutrazol on potted sunflower (Ahmad et al., 2015; Dasoju et al., 1998; Whipker and McCall, 2000; Whipker et al., 2004), the same application method and concentration in this study on swamp sunflower was not different from the control. Expts. 1 and 2 had further height restrictions with plants treated at paclobutrazol rates higher than $4.0 \mathrm{mg} /$ pot (Figs. 1 and 4) which was similarly observed in potted sunflower by Barbosa et al. (2008), who recommended $6 \mathrm{mg} /$ pot for 'Golden', and Vernieri et al. (2003) with a reported $50 \%$ reduction in height at $16 \mathrm{mg} /$ pot (but with variation among cultivars). Dasoju et al. (1998) reported severe retardation in the growth of potted sunflower at 16 and $32 \mathrm{mg} /$ pot. Substrate drench application of flurprimidol at $2 \mathrm{mg} /$ pot by Whipker et al. (2004) restricted the height of potted sunflower by $22 \%$. Similar results were observed in this study at the same PGR rate with a $21 \%$ and $34 \%$ height growth restriction of plants from the control for Expts. 1 and 2, respectively, 4 WAT. In contrast to Whipker et al. (2004), this study found further height restrictions from the control with an increasing rate of flurprimidol (Figs. 1 and 3 ). 


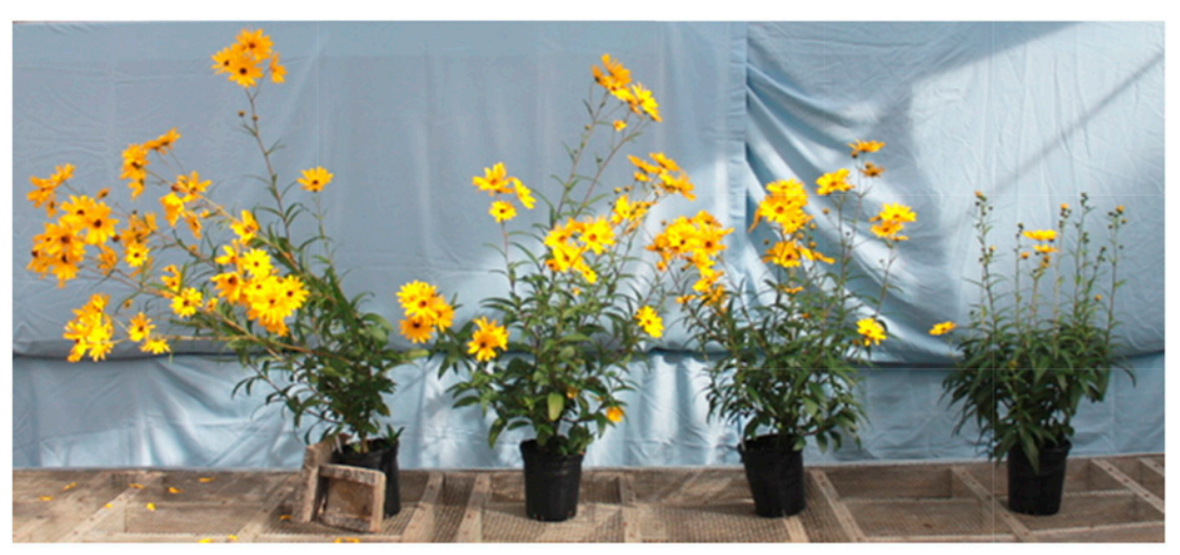

Control

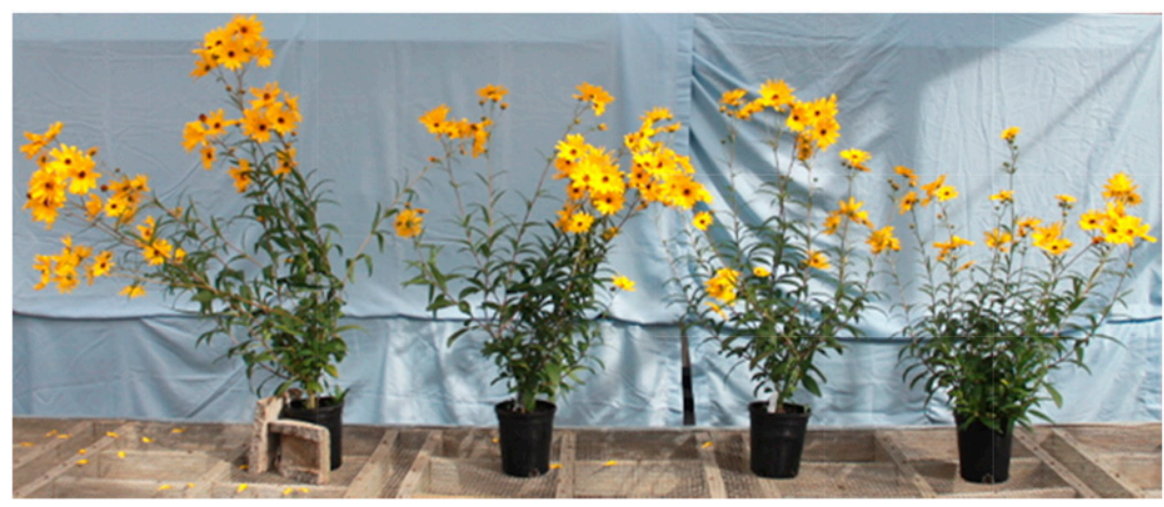

\section{Control | Flurprimidol}

Fig. 5. Effect of the plant growth regulators (PGRs) paclobutrazol and flurprimidol substrate drenches on the growth of container-grown swamp sunflower at 8 weeks after PGR application for Expt. 2 (initiated 7 Sept. 2018). Control had no PGR applied. Paclobutrazol rates were 4, 6, and $8 \mathrm{mg} /$ pot (leftright) and flurprimidol rates applied were 2,4 , and $6 \mathrm{mg} /$ pot (left-right); $1 \mathrm{mg}=$ $3.5274 \times 10^{-5} \mathrm{oz}$.

Chlorophyll meter measurements for paclobutrazol 6.0 and flurprimidol $4.0 \mathrm{mg}$ /pot during Expt. 1 were higher than the control. These results are consistent with those of Ahmad et al. (2015) who observed darker green foliage for 'Pacino Gold' potted sunflower treated with 2 to $4 \mathrm{mg}$ /pot paclobutrazol substrate drenches and for Barbosa et al. (2008) who reported increased chlorophyll meter measurements with increased paclobutrazol substrate drench rates, peaking between 4 to $6 \mathrm{mg} /$ pot for 'Golden' potted sunflower. Increased foliar chlorophyll content with increasing paclobutrazol rate has been reported in additional plant genera to sunflowers [Helianthus sp. (Bañón et al., 2001; Dahab et al., 2015; França et al., 2017)]. Increase in relative chlorophyll with the application of antigibberellin

\section{Paclobutrazol}

delay to anthesis for potted sunflower which was similarly observed by Whipker et al. (2004) with the application of paclobutrazol $(2 \mathrm{mg} / \mathrm{pot}$ drench) or flurprimidol (10-50 $\mathrm{mg} \cdot \mathrm{L}^{-1}$ spray or $0.5-4 \mathrm{mg} /$ pot drench) and by Whipker and Dasoju (1998) with paclobutrazol application of 5 to $40 \mathrm{mg} \cdot \mathrm{L}^{-1}$ as foliar spray. However, delays in flowering of 4 to $6 \mathrm{~d}$ for potted sunflower by PGRs have been reported by Dasoju et al. (1998) with paclobutrazol substrate drench at 2 to $32 \mathrm{mg} /$ pot during winter production and by Whipker and Dasoju (1998) with a foliar spray of paclobutrazol $80 \mathrm{mg} \cdot \mathrm{L}^{-1}$. Flowering delays resulting in less impact to the plants' marketability have been reported for paclobutrazol substrate drenches by Whipker and McCall [2000 ( 2 and $4 \mathrm{mg} / \mathrm{pot})]$ and by Vernieri et al. [2003 (2-16 mg/ pot)], and for flurprimidol (7.5-60 $\mathrm{mg} \cdot \mathrm{L}^{-1}$ foliar spray; Vernieri et al., 2003) on potted sunflower. Plant growth regulator effect on flowering can vary among species with no effect observed by paclobutrazol treatment on pinklady [Dissotis rotundifolia (Hawkins et al., 2015)] or on bulbs of 'Anna Marie' hyacinth [Hyacinthus orientalis (Krug et al., 2005b)], but delays observed from paclobutrazol on african daisy [Osteospermum ecklonis (Barnes et al., 2009)] and by flurprimidol on 'Star Gazer' oriental lily [Lilium hybrids (Krug et al., 2005a)] and 'Anna Marie' hyacinth bulbs (Krug et al., 2005b).

Flower diameter results from compounds in Expt. 2 is likely explained by secondary effects of reduced leaf expansion leading to an increased density of chloroplasts, as well as an increase of chlorophyll biosynthesis (Davis et al., 1988). The lack of increased chlorophyll meter measurements with an increase of PGR rate for Expt. 2 could have been due to the use of foliar resources for inflorescence development (Kitonyo et al., 2018; Leopold, 1961). Interestingly, chlorophyll meter measurements for Expt. I were lower (range: 32.5 to 39.4 ) than for Expt. 2 (range: 40.6 to 43.9 ) for all treatment levels.

Flowering dates for the control and PGR-treated plants occurred between 4 and 8 WAT when treatment was applied 7 Sept. 2018, and no effect on flowering date was observed due to PGR application. There was no Expt. 2 were interesting in that no differences from the control were observed for different PGR rates, but flurprimidol $6.0 \mathrm{mg} /$ pot had a $7 \%$ wider flower than paclobutrazol $6.0 \mathrm{mg} /$ pot. Precedent studies with potted annual sunflower found no differences of flower diameter from control when treated with paclobutrazol substrate drench at 2 or $4 \mathrm{mg} /$ pot (Whipker and McCall, 2000) or as a foliar spray at 5 to $80 \mathrm{mg} \cdot \mathrm{L}^{-1}$ (Whipker and Dasoju, 1998). On the other hand, reductions of flower diameter by application of higher paclobutrazol substrate drench rates (4-32 $\mathrm{mg} / \mathrm{pot}$ ) and flurprimidol spray (60 $\mathrm{mg} \cdot \mathrm{L}^{-1}$ ) have been observed (Dasoju et al., 1998; Vernieri et al., 2003). The number of flowers and flower buds was totaled for each plant to evaluate PGR treatment 
effect on floriferousness; however, no significant pairwise comparisons were found. This parameter was evaluated because an increased number of flowers could increase the marketability of a plant.

In summary, paclobutrazol 4.0 and $6.0 \mathrm{mg} /$ pot and flurprimidol 1.0 , 2.0 , and $4.0 \mathrm{mg} /$ pot applied 25 June 2018 resulted in smaller plants (by GI) at 2 and 4 WAT and less biomass at 6 WAT than the control. After 6 weeks, paclobutrazol 4.0 and 6.0 and flurprimidol 2.0 and $4.0 \mathrm{mg} /$ pot yielded smaller plants than the control. Furthermore, plants treated with paclobutrazol at 4.0 and $6.0 \mathrm{mg} / \mathrm{pot}$ were smaller and had less dry weight than $1.0 \mathrm{mg} /$ pot of the same PGR at 6 WAT. Plants treated with paclobutrazol $6.0 \mathrm{mg} /$ pot and flurprimidol $4.0 \mathrm{mg} /$ pot had higher chlorophyll meter measurements than the control and shorter internodes than the lowest rate of flurprimidol at $6 \mathrm{WAT}$.

For Expt. 2, initiated 7 Sept. 2018, all PGR treatments were smaller (by GI) than the control by 4 and 6 WAT. At termination (8 WAT), plants treated with paclobutrazol $8.0 \mathrm{mg} /$ pot were had less growth in height than plants receiving half that rate. Because the statistical analyses showed no difference in restrictions of plant GI among PGR rates at 4 and 6 WAT in Expt. 2 (Fall 2018), applying the lowest rate of PGR (i.e., flurprimidol at $0.5 \mathrm{mg} /$ pot) would result in a similar smaller size (compared with no PGR) of plants as applying the highest PGR rate (i.e., paclobutrazol at $8 \mathrm{mg} /$ pot). Expt. 2 results also suggest an application of flurprimidol $6.0 \mathrm{mg} / \mathrm{pot}$ over paclobutrazol at the same rate would result in plants with a $7 \%$ wider flower.

In conclusion, optimal PGR substrate drench application rates for reducing overall plant growth of swamp sunflower are paclobutrazol at 4.0 or $6.0 \mathrm{mg} /$ pot or flurprimidol at 2.0 or $4.0 \mathrm{mg}$ /pot. Plants treated with these PGR and rate combinations appeared upright and compact (Figs. 2 and 5), particularly compared with no PGR application. Application of paclobutrazol at 4.0 or $6.0 \mathrm{mg} /$ pot would result in plant sizes $27 \%$ to $29 \%$ or $34 \%$ to $35 \%$ less, respectively, compared with no PGR application for about 2 to 6 weeks. For flurprimidol, application of 2.0 or $4.0 \mathrm{mg} / \mathrm{pot}$ would result in plant sizes $30 \%$ or $50 \%$ less, respectively, compared with no PGR application after 4 weeks.

\section{Literature cited}

Ahmad, I., B.E. Whipker, and J.M. Dole. 2015. Paclobutrazol or ancymidol effects on postharvest performance of potted ornamental plants and plugs. HortScience 50:1370-1374.

Bañón, S., J. Ochoa, and A. González. 2001. Manipulation of oleander growth, development and foliage colour by paclobutrazol and ethephon. Gartenbauwissenschaft 66(3):123-132.

Barbosa, J.G., M.S. Barbosa, S.S. Tsuji, M.A. Muniz, J.A.S. Grossi, and M. Rubim. 2008. Cultivation of ornamental sunflower (Helianthus annums) in vase under different paclobutrazol doses. Rev. Bras. Hort. Ornam. 14(2):205-208.

Barnes, J., B. Whipker, W. Buhler, and I. McCall. 2009. Osteospermum growth control with paclobutrazol substrate drenches. Proc. Annu. Mtg. Plant Growth Regulat. Soc. Amer. 36:96-99.

Dahab, A.M.A., E.A. Khella, and K.A. Emam. 2015. Effect of pinching and paclobutrazol $(\mathrm{Pbz})$ on vegetative growth of Russelia equisetiformis for using as a pot plant. Egypt. J. Hort. 42(2):913-930.

Dasoju, S., M.R. Evans, and B.E. Whipker. 1998. Paclobutrazol drenches control growth of potted sunflowers. HortTechnology 8:235-237.

Davis, T.D., G.L. Steffens, and S. Narendra. 1988. Triazole plant growth regulators. Hort. Rev. 10:63-105.

Flora of North America. 2006. Helianthus simulans, p. 164. In: Flora of North America. Vol. 21. 16 Oct. 2018. <http:// www.efloras.org/florataxon.aspx?flora id=1\&taxon_id=250066901 $>$.

França, C.F.M., L.C. Costa, W.S. Ribeiro, T.D.C. Mendes, M.N.S. Santos, and F.L. Finger. 2017. Evaluation of paclobutrazol application method on quality characteristics of ornamental pepper. Ornam. Hort. 23(3):307-310.

Hawkins, S.M., J.M. Ruter, and C.D. Robacker. 2015. Spray and drench treatments of paclobutrazol influence growth of Dissotis and Tibouchina. HortScience 50:1514-1517.

Heiser, C.B.J., D.M. Smith, S.B. Clevenger, and W.C.J. Martin. 1969. The North American sunflowers (Helianthus). Mem. Torrey Bot. Club 22(3):1-218.

Keever, G.J., W.J. Foster, and J.C. Stephenson. 1990. Paclobutrazol inhibits growth of woody landscape plants. J. Environ. Hort. 8(1):41-47.

Kitonyo, O.M., V.O. Sadras, Y. Zhou, and M.D. Denton. 2018. Nitrogen supply and sink demand modulate the patterns of leaf senescence in maize. Field Crops Res. 225:92-103.

Koutroubas, S.D., G. Vassiliou, and C.A. Damalas. 2014. Sunflower morphology and yield as affected by foliar applications of plant growth regulators. Intl. J. Plant Prod. 8(2):215-229.

Krug, B.A., B.E. Whipker, and I. McCall. 2005a. Flurprimidol is effective at controlling height of 'Star Gazer' oriental lily. HortTechnology 15:373-376.

Krug, B.A., B.E. Whipker, I. McCall, and J.M. Dole. 2005b. Comparison of flurprimidol to ethephon, paclobutrazol, and uniconazole for hyacinth height control. HortTechnology 15:872-874.

Leopold, A.C. 1961. Senescence in plant development. Science 134(3492):17271732 .

R Core Team. 2016. R: A language and environment for statistical computing. 2 Feb. 2019. <https://www.R-project. $\operatorname{org} />$.

Rademacher, W. 2000. Growth retardants: Effects on gibberellin biosynthesis and other metabolic pathways. Annu. Rev. Plant Physiol. Plant Mol. Biol. 51(1):501-531.

Rezazadeh, A. and R.L. Harkess. 2015. Effects of pinching, number of cuttings per pot, and plant growth regulators on height control of purple firespike. HortTechnology 25:71-75.

Syngenta Flowers. 2017. Sunfinity ${ }^{\mathrm{TM}}$ sunflower culture guide. 21 Jan. 2019. <https://www.syngentaflowers-us.com/ file $/ 458846 /$ download $>$.

Vernieri, P., G. Incrocci, F. Tognoni, and G. Serra. 2003. Effect of cultivar, timing, growth retardants, potting type on potted sunflowers production. Acta Hort. 614(1): 313-318.

Watson, E.E. 1929. Contributions to a monograph of the genus Helianthus, p. 30-364. In: E.S. McCartney and P. Okkelberg (eds.). Papers of the Michigan Academy of Science, Arts and Letters. Vol. 9. Univ. Michigan Press, Ann Arbor, MI.

Whipker, B.E. 2013. Plant growth regulator guide. Ball Publ., West Chicago, IL.

Whipker, B.E. and S. Dasoju. 1998. Potted sunflower growth and flowering responses to foliar applications of daminozide, paclobutrazol, and uniconazole. HortTechnology 8:86-88. 
Whipker, B.E. and J.G. Latimer. 2016. Wide assortment of available PGRs, p. 10-12. In: J.G. Latimer (ed.). 20162017 Guide to growing top-quality perennials. Ball Publ., West Chicago, IL.

Whipker, B.E. and I. McCall. 2000. Response of potted sunflower cultivars to daminozide foliar sprays and paclobutrazol drenches. HortTechnology 10:209-211.
Whipker, B.E., I. McCall, J.L. Gibson, and T.J. Cavins. 2004. Flurprimidol foliar sprays and substrate drenches control growth of 'Pacino' pot sunflowers. HortTechnology 14:411-414.

Whipker, B.E., I. McCall, and B.A. Krug. 2006. Flurprimidol substrate drenches and foliar sprays control growth of 'Blue Champion' exacum. HortTechnology 16:354-356.
The Wildlife Center. 2008. Native plant database, Helianthus simulans. 8 Nov. 2018. <https://www.wildflower.org/ plants/result.php?id_plant=HESI2>.

Wunderlin, R.P., B.F. Hansen, A.R. Franck, and F.B. Essig. 2019. Atlas of Florida plants. 11 Feb. 2019. <http:// florida.plantatlas.usf.edu/>. 